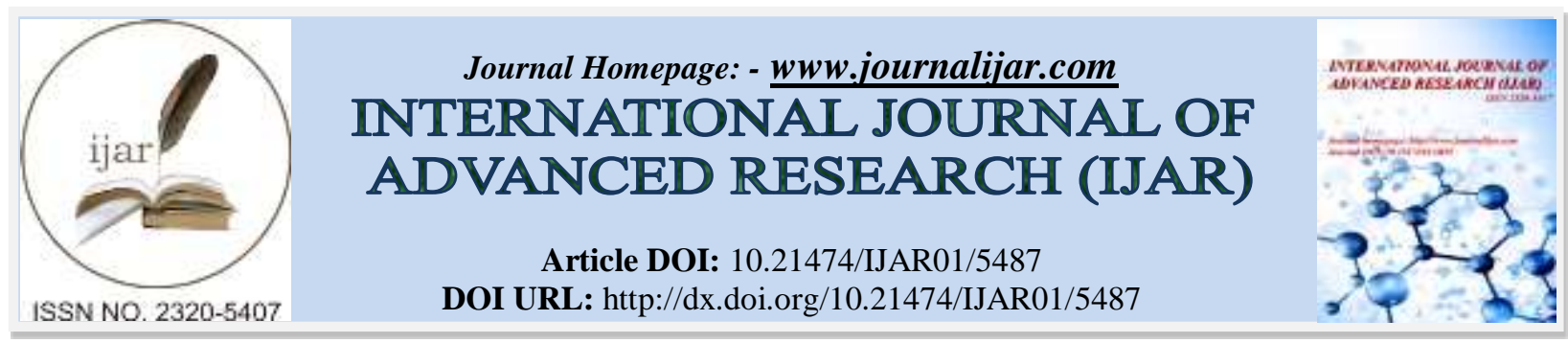

RESEARCH ARTICLE

\title{
A CLINICAL STUDY TO EVALUATE THE EFFICACY OF VIDANGADI CHURNA IN THE MANAGEMENT OF OBESITY.
}

Dr. Marasinghe Pathiranage Nadeeka Pramodani ${ }^{1}$ and Dr. Wasantha Janaki Wickramarachchi ${ }^{2}$.

1. Lecturer, Department of Chikitsa, Gampaha Wickramarachchi Ayurveda Institute, University of Kelaniya, Sri Lanka.

2. Senior Lecturer, Department of Chikitsa, Gampaha Wickramarachchi Ayurveda Institute, University of Kelaniya, Sri Lanka.

\section{Manuscript Info}

Manuscript History

Received: 21 July 2017

Final Accepted: 23 August 2017

Published: September 2017

Key words:-

Obesity, Staulya,Vidangadi churna.

\section{Abstract}

Obesity is defined as a state of excess adipose tissue mass and person with Body Mass Index (BMI) $>30 \mathrm{~kg} / \mathrm{m}^{2}$. It is the cumbersome fettle of today's world as in every region of the world, obesity has doubled between 1980 and 2008, and today, half a Billion people (12\% of the world's population) are considered as obese. This is indeed a careworn situation; Obesity provides the platform for so many hazards like Hypertension, Coronary Heart Diseases, Diabetes Mellitus, Infertility, Impotency as well as psychological disorders like, stress, anxiety. Hence in order to have best management of Obesity present research was carried out. The term Sthaulya is described in Ayurveda for obesity.

Thirty obese patients were selected randomly and treated with Vidangadi churna mentioned in traditional treatments in Sri Lanka. Five grams of Vidangadi churna were given morning and evening for one month and three months follow up period. Patients were assessed under the objective criteria.

The reduction of body weight, reduction observed in B.M.I, reduction in waist to hip ratio were highly significant $(\mathrm{p}<0.001)$. Mid arm circumference were clinically reduced but statistically not significant.

The conclusion of the present study was Vidangadi churna proved to be efficacious in the disease obesity.

Copy Right, IJAR, 2017,. All rights reserved.

\section{Introduction:-}

In recent decades, there has been a significant increase in overweight and obesity prevalence rates in many countries around the world. According to the WHO, 'excess body weight poses one of the most serious public health challenges of the $21^{\text {st }}$ century ${ }^{1}$

A change in life styles creates several different types of health problems including physical, mental, economical and social. The advancement of industrialization and communication is contributing towards sedentary life style, in turn causing chronic non communicable diseases like Diabetes mellitus, Hypertension, Cancer, Ischemic heart disease, Cerebrovascular accidents, Atherosclerosis, Varicosity etc ${ }^{2}$

Corresponding Author:- Marasinghe Pathiranage Nadeeka Pramodani.

Address:-Lecturer, Department of Chikitsa, Gampaha Wickramarachchi Ayurveda Institute, University of Kelaniya, Sri Lanka. 
Obesity is the final common pathway of a complex array of genetic, physiological, nutritional, psychological and cultural influences. Among these social and cultural factors are perhaps the most ubiquitous, social and psychological consequences of obesity include stigmatization and discrimination, down word social mobility, decreased work capacity and dramatic economic losses.

Obesity is a major health problem. Obesity avert the high risk conditions like dyslipidemia, hypertension, coronary artery disease, type 2 diabetes mellitus, osteoarthritis, infertility, impotency, as well as psychological disorders like stress, anxiety, depression, etc. Overweight and obesity linked to more deaths than the underweight.

According to WHO obesity is measured by the Body Mass Index (BMI), state as a BMI greater than or equal to 25 is overweight and a BMI greater than or equal to 30 is obesity. ${ }^{3}$

Ayurvedic classics give sufficient focus on obesity (sthaulya or medoroga) and serves as a guideline to advise diet, shodana karma,drugs etc. present or to control the disease.

Present work was conducted on Vidangadi churna having antiobesity properties as mentioned in Traditional Medicine in Sri Lanka.

\section{Materials and methods:-}

Drug preparation:-

Equal quantity of dry powders of Embelia ribes, Terminalia chebula, Phyllanthus emblica, Zingiber officinale Zingiber officinale and Ricinus communis were mixed together to make Vidangadi churna.

The 30 patients of Sthaulya (obesity) attending for clinics in Gampaha Wickramarachchi Ayurveda Hospital, Yakkala, Sri Lanka,fulfilling the criteria of the disease were selected for present study.

\section{Criteria of diagnosis:-}

The diagnosis was mainly based on the clinical presentation as mentioned in the Ayurveda texts as well as Allopathic texts along with body mass index (BMI). A detailed proforma incorporating all the clinical aspects mentioned for Sthaulya/obesity was prepared accordingly, detailed clinical history was taken and physical examination was done.

\section{Inclusion criteria:-}

1. Patients having clinical presentation of Sthaulaya (obesity) with BMI equal or more than 25 and with the age of 20-50 years were included for the present study.

\section{Exclusion criteria:-}

1. Patients in the age group of less than 20 years and more than 60 years were not included for the present study.

2. Obese patients suffering from hypothyroidism, obesity due to hormonal imbalance, cardiovascular diseases, hemiplegia, associated with severe hypertension and from other such diseases in which the patient cannot do his routine physical activities were excluded.

3. Pregnant and lactating women

The patients were treated with $5 \mathrm{~g}$ of Vidangadi churna.(were added to $120 \mathrm{ml}$ of boiled water and remain for 10 minutes and filter ) morning and evening daily for one month and patients were followed for a period of one month after the treatment.

\section{Assessment criteria:-}

The effect of therapy was assessed on the basis of the following objective criteria.

1. Weight

2. $\mathrm{BMI}\left(\mathrm{BMI}=\right.$ weight $(\mathrm{kg}) / \mathrm{Height}(\mathrm{m})^{2}$

3. Mid Arm circumference.

4. Waist to Hip ratio 


\section{Results:-}

All 30 patients completed the study. No patient was dropped out or withdrawn due to the adverse event or an adverse reaction. Study treatment did not cause any significant change in vital signs like pulse rate, body temperature, respiratory rate, and the blood pressure. Of 30 patients included in the trial, 10 (33.33\%) were men while $20(66.67 \%)$ were women.

Patients included in the trial range from 20 years to 60 years of age. Patients from Age group 20-30 yrs (57\%) and $31-40$ yrs (23\%) shows more prevalence.

Out of 30 patients of obesity $07(23.33 \%)$ patients were vegetarian and 23 (76.67\%) patients consuming mixed diet. Consumption of heavy, oily food is causative factor of obesity. Most of the patients were non vegetarian (i.e. Mixed diet) so this data can support the responsible diet factor of obesity.

Of 30 patients of obesity 7 patients (23.33\%) were of Vata-Kapha Prakruti, 16 (53.33\%) patients were of KaphaPitta Prakruti, and 07 (23.33\%) patients were of Vata-Pitta Prakruti. It can be suggested that Kapha Pradhan Prakruti is more prone for obesity.

Out of 60 patients of obesity, 07 (23.33\%) Patients were found with Manda Agni, Vishama Agni was found in 08 (26.67\%) patient. And there were 15 (50\%) of Tikshna Agni. This can be concluded that due to Tikshna Agni patient eats more ultimately causing obesity.

Mean weight in the patients before the treatment was $73.32 \pm 11.02$ and it decreased moderately to $73.01 \pm 10.95$ after the treatment.

Mean BMI in patients before the treatment was $29.68 \pm 2.34$ which was decreased moderately to $28.99 \pm 2.10$.

Mean Mid Arm circumference in patients before the treatment was $34.46 \pm 2.57$ which was decreased slightly to $34.35 \pm 2.76$.

Mean Waist to Hip ratio in patients before the treatment was $0.87 \pm 0.07$ which was decreased moderately to $0.86 \pm$ 0.07 .

All parameters at before and after the treatment found are summarized in Table 01 to 03 Analyzing the results it was found that Experimental drug revealed statistically significant effect on patient's weight, BMI, Waist to Hip ratio. Mid Arm circumference also have been reduced from the treatment but it was not statistically significant.

Table 01:- Mean value of Weight before and after the treatment

\begin{tabular}{|l|l|l|l|l|}
\hline & $\mathrm{N}$ & Mean & StDev & SEMean \\
\hline After & 30 & 73.0167 & 10.9563 & 2.0003 \\
\hline Before & 30 & 73.3267 & 11.0278 & 2.0134 \\
\hline Difference & 30 & -0.310000 & 0.590937 & 0.107890 \\
\hline
\end{tabular}

T-Test of mean difference $=0($ vs $<0)$ : T-Value $=-2.87 \mathrm{P}-$ Value $=0.004$

Table 02:- Mean value of Mid arm circumference before and after the treatment

\begin{tabular}{|l|l|l|l|l|}
\hline & $\mathrm{N}$ & Mean & StDev & SEMean \\
\hline After & 30 & 34.3533 & 2.7693 & 2.0003 \\
\hline Before & 30 & 34.4633 & 2.5730 & 2.0134 \\
\hline Difference & 30 & -0.110000 & 0.391593 & 0.071495 \\
\hline
\end{tabular}

T-Test of mean difference $=0($ vs $<0)$ : T-Value $=-1.54$ P-Value $=0.067$

Table 03:- Mean value of Waist to Hip ratio before and after the treatment

\begin{tabular}{|l|l|l|l|l|}
\hline & $\mathrm{N}$ & Mean & StDev & SEMean \\
\hline After & 30 & 0.862667 & 0.070316 & 0.012838 \\
\hline Before & 30 & 0.872000 & 0.078010 & 0.014243 \\
\hline Difference & 30 & -0.009333 & 0.021804 & 0.003981 \\
\hline
\end{tabular}


T-Test of mean difference $=0($ vs $<0):$ T-Value $=-2.34 \mathrm{P}-$ Value $=0.013$

\section{Discussion:-}

In Ayurveda Obesity is regarded as Medoroga-A disorder of Meda Dhatu- Adipose tissue and fat metabolism and one of the undesirable Constitutions. Sthaulya is considered as a santarpan janya vikar. (An excess nutritional disorder). Aacharya charaka was the first to present a detailed account of Sthaulya. ${ }^{4}$ He has described its causative factors mainly to be exogenous and hereditary type (Bijadosha), its etiopathogenesis, prognosis and management. In the pathogenesis of sthaulya, all the three doshas are vitiated, especially Kledaka Kapha, Pacaka Pitta, Samana and Vyana Vayu are the Doshika factors responsible for the samprapti of sthaulya. Aama annarasa traveling in the body channels gets obstructed in the Medovaha Srotas owing to the khavaigunya due to bijasvabhava or sharir shaithilya and combines with kapha and meda, decreasing the medo dhatvagni which in turn gives rise to augmentation of meda. Vitiated Vyana Vayu propels this augmented meda dhatu to its sites viz.udara (abdomen), sphika(hip region), stana(breast), gala(neck) etc. resulting in sthaulya or atiSthula. Chala sphika, chala udar, chala Stana and ati meda-mamsa vrddhi are very obvious in all the patients of sthaulya. Manifestations of these Rupas are associated with either excessive accumulation of meda dhatu or diminished nourishment of other dhatus or obstruction in various Srotas(channels) by medojanya margavarodha or the aama or vitiation of vata and slesma Dosa, so excessive accumulation of Medo Dhatu produces various signs and symptoms in Sthaulya patient. ${ }^{5}$

Most of the drugs of Vidangadi churna is having Dipana, Pachana, Kaphaghna, Shothahara Lekhana, and VataKapha Hara properties. Predominance of Katu, tikta and kasaya rasa

pacifies kapha. Rukshana property helps to reduce fat in the body and Chedaneeya property helps to remove obstruction in the channels, particularly from channel related to fat by its sroto cleansing property. Also synergistic action of herbs helps to increase Bhutaagni and corrects the functions of Dhatvaagni and may correct the pathogenesis of Obesity.

\section{Conclusion:-}

It can be concluded that Vidangadi churna is effective in managing Obesity.

\section{Reference:-}

1. World Health Organisation (2007) The challenge of obesity in the WHO European Region and the strategies for response, World Health Organisation: 1.

2. Joshi S, Deole SD, Vysa GH, DASH SC et al.Management of overweight and obesity through specific yogic procedures AYU an international quarterly journal of research in Ayurveda 2009; 30:4

3. http;www.who.int/topics/obesity/en/

4. Charak Samhita with Ayurved Dipika Tika and Jalpakalpataru Tika - Chaukhambha Orientalia, Varansi, 1991.

5. Charak Samhita (Eng.) - Shree Gulabkunvarba Ayurvedic Society, Ist. Edi.Jamnagar , 1949. 